\title{
Mind Sciences in the Harvard Law School Curriculum: Tracing the History, Proposing the Proliferation
}

\section{Citation}

Tito Rendas, Mind Sciences in the Harvard Law School Curriculum: Tracing the History, Proposing the Proliferation (2012).

\section{Permanent link}

http://nrs.harvard.edu/urn-3:HUL.InstRepos:9299796

\section{Terms of Use}

This article was downloaded from Harvard University's DASH repository, and is made available under the terms and conditions applicable to Other Posted Material, as set forth at http:// nrs.harvard.edu/urn-3:HUL.InstRepos:dash.current.terms-of-use\#LAA

\section{Share Your Story}

The Harvard community has made this article openly available.

Please share how this access benefits you. Submit a story.

\section{Accessibility}




\title{
Mind Sciences in the Harvard Law School Curriculum: Tracing the History, Proposing the Proliferation
}

\author{
Tito Rendas ${ }^{1}$
}

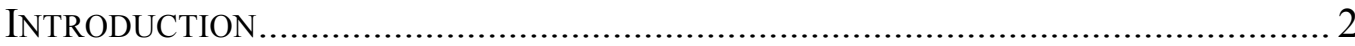

I. HistoricAl AND IDEOLOGICAL Foundations of LAW AND Mind SCIENCES AT

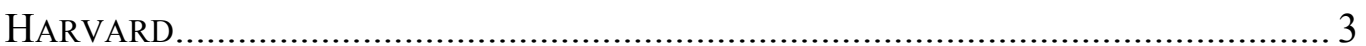

II. MiND SCIENCES IN THE HLS CURRICULUM FROM 1957 TO 2013 ...................... 7

1. 1957-64: Auguries of Mind Sciences ...................................................... 9

2. 1964-69: Inception of the Mind Sciences in the HLS Curriculum......... 10

3. 1969-89: The First Stabilization Period ................................................ 15

4. 1989-97: The First Golden Period ........................................................ 16

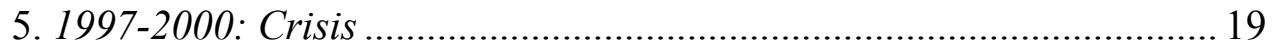

6. 2000-10: The Second Golden Period .................................................... 19

7. 2010-13: The Second Stabilization Period ............................................ 25

III. The Case for the Proliferation of LaW And Mind Sciences Courses in THE LAW SCHOOL CURRICULUM.................................................................. 25

1. Are Mind Sciences a Fundamental Part of the "Good Law

Curriculum"? .......................................................................................... 25

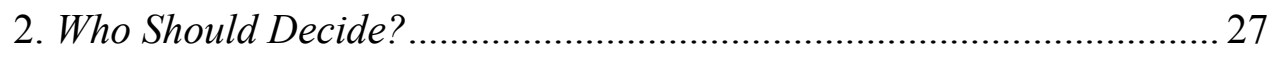

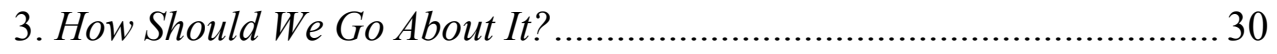

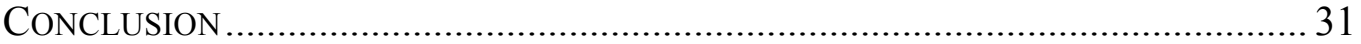

\footnotetext{
${ }^{1}$ LL.M., 2012, Harvard Law School, Cambridge, MA, U.S.A.; LL.M., 2011, Católica Global School of Law, Lisbon, Portugal; LL.B., 2010, Universidade Católica Portuguesa, Lisbon, Portugal. I am grateful to Professors Adam Benforado, Joshua Greene, Jon Hanson, Dan Kahan, and Alan Stone for sharing their thoughts on some of the issues covered in this paper and for giving me information to chew on, to Professor Dan Coquillette and my colleagues in the seminar "Legal History: American Legal Education" at Harvard Law School for helpful suggestions and comments, and to Kara Ruggiero for her patience during the days I spent in the Registrar's Office perusing course catalogues. Any errors remain the product of my own mind.
} 


\section{INTRODUCTION}

"Ferment is abroad in the law. The sphere of interest widens; men become interested again in the life that swirls around things legal. ...

Whether this ferment is one thing or twenty is a question; if one thing, it is twenty things in one. But it is with us. It spreads. It is no mere talk. It shows results, results enough through the past decade to demonstrate its value."

- Karl N. Llewellyn ${ }^{2}$

This paper explores the contours of the relationship between the mind sciences and the Harvard Law School curriculum, in particular, and the law curriculum more generally. Rather than using a conceptual definition of "mind sciences", the paper will be based on an illustrative and fairly loose definition thereof. Any discipline that delves into the mechanisms that explain the functioning of the human mind and the reasons behind human behavior is considered a mind science for purposes of this study. Psychology, psychiatry, cognitive science, and neuroscience are examples of the disciplines that fit under the scope of this definition. Apart from this short introduction, the paper is divided into three more parts.

Part I discusses the ideological sources of the relatively recent law and mind sciences movement at Harvard. Particular consideration will be given to the role played by the legal realists in questioning assumptions that would otherwise prevent the mind sciences from permeating law and policy-making. Roscoe Pound was a figure of great importance to the mind sciences' venture at Harvard by advocating a psycho-legal realism and by hiring Sheldon Glueck, a pioneer of empirical mind research along with his wife Eleanor, for the faculty. As it shall be seen, however, Pound did not remain a believer in the virtues of legal realism for long.

Part II conducts an extensive historical review of the law and mind sciences courses in the HLS curriculum from 1957 to 2013. Six trends, and a predicted future trend, were identified. A distinction that will be used throughout this paper, that between "perfect" law and mind sciences courses and "imperfect" law and mind sciences courses, will be explained.

Part III is normative in its essence, making the case for the expansion of the law and mind sciences curriculum. This argument is predicated on the answers to two other questions: Who should decide whether this expansion should be carried out? And, assuming its desirability, how should we go about it? The answers to these questions can be found in Part III.

${ }^{2}$ Karl N. Llewellyn, Some Realism About Realism - Responding to Dean Pound, 44 HARV. L. REV. 1222, 1222-23 (1931). 


\section{HistoricAl AND IDEOLOGICAL Foundations of LAW AND Mind SCIENCES AT HARVARD}

Legal realism, characterized by a belief in the indeterminancy of law, an antiformalistic understanding of legal reasoning, and a call for social empiricism, ${ }^{3}$ planted the theoretical seed that decades later originated the law and mind sciences movement. ${ }^{4}$ Like scholars of law and psychology presently, the legal realists were skeptical of many of the assumptions built into our laws and legal theories. Without the institution of this skepticism as a common element in legal discourse, a great part of the currently available law and mind scholarship would have probably never seen the light of day. If contemporary legal scholars wouldn't have been exposed to ${ }^{5}$ and assimilated the realist idea that rules run out on legal decision-makers - i.e., that there is often leeway for multiple readings of the same rule and that for almost every case there is a rule and a counter-rule that would provide an opposite outcome - they wouldn't have felt the need to, e.g., go Inside the Judicial Mind, ${ }^{6}$ to enquire into How Judges Decide Cases, ${ }^{7}$ or to examine the Social Psychology of Jury Deliberations. ${ }^{8}$

It is important to note, however, that " $[\mathrm{t}]$ he realists did not believe ... that the indeterminancy of legal rules meant that all generalizations are meaningless and that decisions are controlled only by the psychological make-up of the

${ }^{3}$ See generally, e.g., the following seminal works by Felix Cohen and Karl Llewellyn: Felix S. Cohen, The Ethical Basis of Legal Criticism, 41 YALE L.J. 201 (1931); Felix S. Cohen, Transcendental Nonsense and the Functional Approach, 35 COLUM. L. REV. 809 (1935); and Llewellyn, supra note 2.

${ }^{4}$ Some accounts point to the work of Hugo Munsterberg in the early 1900s as the inception of law and psychology in the U.S. See Jeremy A. Blumenthal, Law and Social Science in the Twenty-First Century, 12 S. CAL. InTERDISC. L.J. 1, 7 (2002-2003), referring to HuGO Munsterberg, On the Witness StAnd (1908); and Hugo Munsterberg, Yellow Psychology, 11 LAW NoTES 145 (1907).

${ }^{5}$ Social psychology as an explanation to offer for this too: the mere exposure effect. The mere exposure effect is " $[\mathrm{t}]$ he finding that repeated exposure to a stimulus (e.g., an object or a person) leads to greater liking of the stimulus." Perhaps because of having learned the law from scholarship imbued with the legal realist spirit or because of having been taught by legal realists, contemporary legal scholars ended up developing a liking for the tenets of legal realism. Thomas Gilovich, Dacher Keltner, \& Richard E. Nisbett, Social Psychology 362 (second edition, 2011).

${ }^{6}$ See Chris Guthrie, Jeffrey J. Rachlinski \& Andrew J. Wistrich, Inside the Judicial Mind, 86 CORNELL L. REV. 777 (2001).

${ }^{7}$ See Chris Guthrie, Jeffrey J. Rachlinski \& Andrew J. Wistrich, Blinking on the Bench: How Judges Decide Cases, 93 CORNELL L. REV. 1 (2007).

${ }^{8}$ See Garold Stasser, Norbert L. Kerr \& Robert M. Bray, The Social Psychology Of Jury Deliberations: Structure, Process, and Product, in The Psychology of the Courtroom 221 (Norbert L. Kerr \& Robert M. Bray eds., 1982). 
judge." 9 Llewellyn argued that decision-makers exercise a common professional "situation sense" that allows them to grasp the meaning that should impregnate highly abstract legal concepts. These shared understandings of the law, Llewellyn claimed, are crucial in determining the outcomes of cases - more so than the individual dispositions of legal decision-makers. ${ }^{10}$ But that does not invalidate my claim that legal realism is the ideological seed of law and mind sciences. Legal realists paved the way for the law and mind sciences not by advocating that the foundations of legal decisions lie in psychological factors, but in a more subtle way: By popping up the formalist balloon, the realists made the legal scholarly community understand that the true reason for the outcome of cases does not lie on legal rules alone. Harvard Law Professor Joseph Singer, summarizing the influence of legal realism on legal thought, wrote that

[it] has fundamentally altered our conceptions of legal reasoning and of the relationship between law and society. The legal realists were remarkably successful ... in changing the terms of legal discourse .... All major current schools of thought are, in significant way, products of legal realism. To some extent, we are all realists now. ${ }^{11}$

And if legal realism laid the ideological foundations of the law and mind sciences movement in general, Roscoe Pound, precisely by endorsing legal realism, did so at Harvard. In 1931, during his deanship, Pound published The Call for a Realist Jurisprudence, ${ }^{12}$ where he delineates "a program of relativist-realist jurisprudence". 13 This program of jurisprudence was based on a series of elements, among which was "A theory of interests and of the ends of the legal order based on or consistent with modern psychology." 14 Such proposal was advanced in the wake of the recognition that "[p]sychological exposure of the rôle of reason in human behavior, of the extent to which so-called reasons come after action as explanations instead of before action as determining factors, has made a profound impression upon the rising generation of jurists." ${ }^{15}$ Moreover, "[a]long with the assertion that the sole valid approach is by way of psychology",

\footnotetext{
${ }^{9}$ Joseph W. Singer, Legal Realism Now, 76 CALIF. L. REV. 465, 470 (1988) (reviewing Laura Kalman, Legal Realism at Yale, 1927-1960 (1986)).

${ }^{10}$ Jerome Frank, on the other hand, seemed to assign greater weight to the individual differences between judges and their background. See Jerome Frank, LAW AND the Modern MiND (1930).

${ }^{11}$ Singer, supra note 9 , at 467.

${ }^{12}$ Roscoe Pound, The Call for a Realist Jurisprudence, 44 HARV. L. REV. 197 (1931).

${ }^{13} \mathrm{Id}$., at 710 .

${ }^{14} I d$., at 711.

${ }^{15} I d$., at $704-5$.
} 
Pound associated with legal realism "a presupposition that some one psychological starting point is the unum necessarium" for legal reasoning. ${ }^{16}$ Regardless of whether or not legal realists identified themselves with this description (Llewellyn seemed to find a substantial part of Pound's description to be inaccurate ${ }^{17}$ ), Dean Pound's account represents a very powerful endorsement of legal realism as psychological realism ${ }^{18}$ at Harvard Law School.

Before making this endorsement, however, Dean Pound had already taken practical measures that were in line with the essence of this psychological realism that he believed to be the way forward in legal jurisprudence. Pound's belief that not only law professors, but also judges and lawyers, should draw on the teachings of social sciences and empirical studies in making law develop, ${ }^{19}$ had repercussions in his hiring decisions. In 1929, Pound offered Sheldon Glueck a position as assistant professor, while his wife, Eleanor Glueck, had already become a research assistant at the Law School in 1928, where she would work for the rest of her life. ${ }^{20}$ Sheldon, who later became the first Pound Professor of Law, and Eleanor formed "a husband-and-wife team whose numerous studies of criminal behavior and of the results of correctional treatment profoundly

${ }^{16} I d$. at 705 .

${ }^{17}$ In his response to Pound, Llewellyn sharply criticized some points of the Dean's description of the legal realists. Specifically, Llewellyn found that none of the twenty scholars representative of the legal realist movement had ever supported the " presupposition that some one of the competing psychologies is the unum necessarium for jurisprudence." Llewellyn, supra note $2,1230-31$.

${ }^{18}$ More recently, other authors have proposed an understanding of legal realism as psychological realism. See Donald Braman \& Dan M. Kahan, Legal Realism as Psychological and Cultural (not Political) Realism, in How LAw KNows (A. Sarat, L. Douglas, \& M. Umphrey eds., 2007) (claiming that a conception of legal realism that would recognize the influence of cultural values on human decision-making, and thus on law, would provide a more accurate account of the legal system than the traditional realism).

${ }^{19}$ This belief was made public as early as 1911, when Pound published The Scope and Purpose of Sociological Jurisprudence, before becoming Dean of Harvard Law School. See Roscoe Pound, The Scope and Purpose of Sociological Jurisprudence, 24 HARV. L. REV. 591 (1911), 25 HARV. L. REV. 140 (1911-12).

${ }^{20}$ For a concise, yet very complete, biography of Eleanor Glueck, including a description of the work she conducted with her husband, see BARBARA SICHERMAN \& CAROL H. Green (eds.), Notable American Women: The Modern Period: A Biographical DICTIONARY 278-80 (1986). It is interesting to note that Eleanor became a research associate in 1953, but was never offered a position as professor. In 1972, the year of Eleanor's death, HLS granted tenure to a woman for the first time. See Emily Newburger, A Class Unto Themselves, Harvard Law Bulletin (Summer 2003), http://www.law.harvard.edu/news/bulletin/2003/summer/feature_3-1.html, and Susan F. Kinsley, Harvard's Affirmative Action Plan: Slow Progress for Women, Blacks, The Harvard Crimson (1973), http://www.thecrimson.com/article/1973/6/14/harvards-affirmative-action-plan-slowprogress/. 
influenced criminal justice, both legislatively and administratively." ${ }^{21}$ Inspired by Richard C. Cabot of the Harvard's Department of Social Ethics, Sheldon and Eleanor started conducting follow-ups of criminals sentenced to reformatories. ${ }^{22}$ Sheldon and Eleanor became pioneers in empirical mind research applied to the study of criminal character and behavior, and published a series of books detailing their studies. "The Gluecks worked together closely on each book: Sheldon had a penchant for the legal, psychiatric, and literary aspects of the work, while Eleanor's province was the practical, statistical, and field work."23 They later narrowed down their interest to the problem of juvenile delinquency and, in 1950, published the results of an ambitious project directed at understanding "the causes, prevention, prediction, and treatment of juvenile delinquency" ${ }^{24}$ in Unraveling Juvenile Delinquency. ${ }^{25}$ The interest in juvenile delinquency came up as a natural combination of their distinct and eclectic educational backgrounds: Sheldon had a Ph.D. crosscutting the areas of sociology, law, and psychiatry, while Eleanor had a masters (Ed.M.) and a doctorate (Ed.D.) in education. ${ }^{26}$

In sum, in terms of interdisciplinary research involving contributions from the mind sciences, Sheldon and Eleanor were ahead of their time. Their recruitment can be considered a practical repercussion, even if only a modest one, of Dean Pound's belief that Harvard Law School needed faculty who sought guidance in social empiricism and mind sciences in conducting their studies. But, regardless of having remained a mentor of Sheldon's and an active fundraiser for his and Eleanor's research, it didn't take long for Pound to change his mind regarding the influence that legal realism as he conceived it to be, and hence of psychology and empirical studies, should play in legal education. Only a year after the publication of The Call for a Realist Jurisprudence, Pound was "accus[ing] the law professors he labeled realists of exaggerating the unreliability of legal rules, blindly engaging in empirical work without considering its purpose, overemphasizing judicial psychoanalysis, and neglecting the role of moral values in law." ${ }^{27}$ Psychology, Pound argued, should be studied in college, not in law school. ${ }^{28}$ According to Laura Kalman, Pound's assertions against legal realism succeeded in keeping its influence away from the HLS curriculum and faculty

21 Sheldon Glueck and Eleanor Glueck, Britannica Online Encyclopaedia, http://www.britannica.com/EBchecked/topic/1353094/Sheldon-Glueck-and-Eleanor-Glueck .

${ }^{22}$ See id., and SICHERMAN \& GREEN, supra note 20, at 279.

${ }^{23}$ SICHERMAN \& GREEN, supra note 20, at 279.

${ }^{24} \mathrm{Id}$.

${ }^{25}$ See Sheldon Glueck \& EleAnor Glueck, UnRAVEling JuVEnile DelinQuency (1950).

${ }^{26}$ See John H. Laub \& Robert J. Sampson, The Sutherland-Glueck Debate: On the Sociology of Criminological Knowledge, 96 AMERICAN JOURNAL OF SOCIOLOGY 1402 (1991).

${ }^{27}$ LAURA KALMAN, LEGAL REALiSM AT YALE, 1927-1960 46 (1986).

${ }^{28}$ See id., at 56. 
recruitment: innovativeness was not a characteristic of HLS professors and the marasmus was permeating the curriculum. ${ }^{29}$ The consequence, Kalman suggests, was a "reluctance to expand the curriculum to increase students' awareness of law's relationship with the social sciences", including psychology, reluctance which was due to "a fear of being perceived as "soft.",30

It bears noting, however, that this part of the paper is not intended to be an investigation of the history of legal innovations, in general, and legal realism, in particular, at HLS. Its goal, which I hope to have fulfilled, was to provide a general understanding of the theoretical movements that preceded the birth of law and mind sciences at Harvard, and that serve as the background for the curricular analysis that follows.

\section{MIND SCIENCES IN THE HLS CURRICULUM FROM 1957 TO 2013}

In this part of the paper, I will report the findings of a study that involved going over fifty-three course catalogues in order to identify courses in law and mind sciences in the HLS curriculum. ${ }^{31}$ Catalogues were available in print from 1957 to 2005 . The catalogues from 2005 onwards could be found online. ${ }^{32}$

Before moving into an analysis of the findings of this study, a distinction that will be used throughout the paper must be apprehended: that between "perfect" law and mind sciences courses and "imperfect" law and mind sciences courses. This duality, admittedly a subjective one, aims at differentiating between i) courses that either directly explore the intersection between law and a particular science of the mind (which will typically be "law and" courses, like "Law and Cognition", "Law and Neuroscience", "Law and Psychology"), discussing the implications of that particular science for legal decision-making and legal theory, or that explore another topic, but do so by drawing mainly from insights of one or more mind sciences (e.g., "The Prediction and Prevention of Harmful Conduct", "Negotiation: Dealing with Emotions"), and ii) courses that assign some readings on psychology and other mind sciences and that discuss their contributions to a thorough understanding of the course topic, but that don't have their crux in that discussion. The former are what I call "perfect law and mind sciences courses"; the latter "imperfect law and mind sciences courses". The subsumption of a course in either of these two categories was entirely

${ }^{29}$ See id., at 64 .

${ }^{30} \mathrm{Id}$., at 66 .

${ }^{31}$ The 1972-73, 1973-74, and 1982-83 catalogues were missing.

${ }^{32}$ The course catalogues from 1957 to 2005 can be found in the HLS Registrar's Office and can be consulted upon request. The catalogues from 2010 to 2013 are available at http://www.law.harvard.edu/academics/curriculum/catalog/. For the catalogues of the years 2005 to 2009, I used the Wayback Machine (http://archive.org/web/web.php), a service that enables users to consult archived versions of webpages across time. 
discretionary. If the categorization of some courses is clear-cut - normally, courses that are undoubtedly "perfect" courses, like the "law and's" - the line between courses that draw substantially on insights of mind sciences, and courses that draw on those insights, but not in a substantial way, is a blurry one. Some heuristics were used in the process of categorization. For instance, if a course was in the borderline between perfect and imperfect, but was taught by someone with training in mind sciences or that had consistently been teaching "perfect" courses throughout his or her career, I would consider the course a "perfect" course.

Six different trends, and one predicted future trend, of the presence of the mind sciences in the law curriculum were identified. Although these trends can be spotted in the chart below in a pretty clear way, it bears noting that they too are the product of a subjective judgment: First, because they are based essentially on the abovementioned distinction. Even though I will present and discuss the influence of some of the "imperfect" courses, these courses were not considered for purposes of identifying the trends. The chart is representative of the evolution of the presence of "perfect" courses only. Second, because I used no baselines to identify these trends. The trends were not identified because during a certain number of consecutive years the number of mind sciences courses was above or below a certain baseline; they were extracted from the patterns yielded by the graph and are relative to each other.

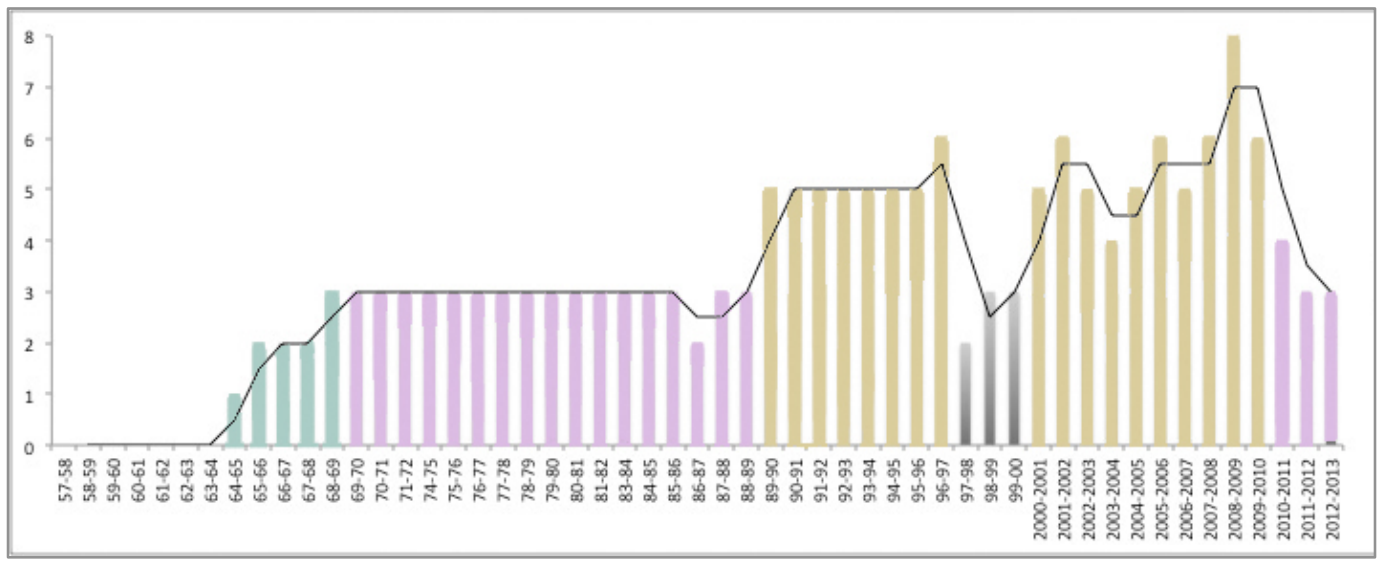

Figure 1 - Column chart and moving average line representing the evolution of the number of "perfect" law and mind sciences courses from 1957 to 2013. The different trends are represented with different colors: green for the "birth"; pink for the stabilization periods; golden for the golden periods; and grey for the crisis. 
Moreover, it must be noted that the character of the paper is one of sole exploration: it merely analyzes the trends in terms of the absolute number of law and mind sciences courses offered over time. In other words, the following analysis is based on raw numbers, and not on a proportion of mind sciences courses over the total number of courses offered per year. The possibility that this proportion has decreased throughout these fifty-six years is a real one. My intuition tells me that the number of mind sciences courses per total number of courses has, in fact, decreased, much like what must have happened with almost all the other subject areas, due to the boom in total number of courses that occurred around the 1970 s - a number that has been permanently increasing.

\section{1957-64: Auguries of Mind Sciences}

The period between 1957, year that marks the beginning of my study, and 1964 shows only some modest contributions of the mind sciences to the HLS curriculum. From 1957 to 1963, Sheldon Glueck was still a member of the faculty at HLS, where he taught a course that reflected his and his wife's main research interest: "The Problem of Juvenile Delinquency", a seminar which dealt "with the legal, social and psychiatric problems pertaining to child delinquency and embryonic criminalism." "33 Apart from Glueck's course, only one more course had a connection with the mind sciences. In "Medico-Legal Problems", William J. Curran explored "the relation of law and medicine, particularly the considerations involved when members of the legal and health professions must cooperate in analyzing major medico-legal problems." 34 One of the many topics discussed was "legal psychiatry including orientation to human behavior and determination of mental competence.",35

During this period, Yale Law School was taking concrete steps to increase the influence of the mind sciences over its students. In 1961, Dean Eugene Rostow invited Anna Freud to join the faculty, of which Jay Katz, a psychoanalyst, and Joseph Goldstein, a scholar whose "greatest impact on legal scholarship and practice was in the intersection among the disciplines of law, psychiatry and psychoanalysis", 36 were already members. As visiting professor, Anna Freud would participate in class meetings in "Family Law" and "Criminal Law" - taught, respectively, by Katz and Goldstein, who would incorporate a great deal of psychiatry and psychoanalytic theory into their teaching - and

${ }^{33}$ The Catalogue of the Law School, LIV Official Register of Harvard University 55 (1957-58).

${ }^{34} I d$., at 58.

${ }^{35} \mathrm{Id}$.

${ }^{36}$ Obituary: Joseph Goldstein Sterling Professor Emeritus of Law at Yale Law School, http://news.yale.edu/2000/03/15/obituary-joseph-goldstein-sterling-professor-emeritus-law-yalelaw-school. 
teach a seminar in "Psychoanalysis and Jurisprudence". ${ }^{37}$ At the same time, at Harvard, apart from the two mentioned courses bridging the gap between some legal and social policy topics and psychiatry, no other source of influence of the mind sciences in the HLS curriculum existed. Hence the title of this trend: auguries are but signs of something that is coming. These two courses can hardly be considered to constitute the birth of the mind sciences in the law curriculum; but they somehow indicate that some curricular phenomenon is about to unfold. If that phenomenon was a spontaneous one or a reaction to what was happening at Yale is something that one can only speculate about.

\section{1964-69: Inception of the Mind Sciences in the HLS Curriculum}

The curricular year of 1964-65 saw the birth of "perfect" mind sciences courses in the HLS curriculum. "Designed to familiarize the law student with theories of behavior and to explore their relevance to legal problems" 38 , the course in "Psychiatry, Psychoanalysis and the Law" reflected an awareness of the importance of studying the workings of the psyche in order to attain a genuine understanding of certain legal topics. The course focused on "one particular theory of behavior: psychoanalytic. With basic concepts of this theory in mind though constantly reexamined and challenged - [it] ... explored their utility in giving content to one pervasive legal concept: "competency'." 39 It is curious to note that the course was taught by then Assistant Professor Alan Dershowitz, who graduated from Yale Law School with a Bachelor of Laws (LL.B.) in 1962, with the participation of Jay Katz, Associate Professor of Law and Associate Clinical Professor of Psychiatry at Yale. Dershowitz, despite never having been taught by Anna Freud, who started teaching at Yale precisely in 1962, was inspired by the approach adopted by Katz and Goldstein in the courses they taught at Yale, and brought that approach into the Harvard classrooms.

The course suffered some changes in the years that followed its introduction in the curriculum. In 1965, the course seems to be split in two: one course dealing mainly with the interconnections among psychoanalytic theory and the law; ${ }^{40}$ and the other dealing with the issue of mental illness ${ }^{41}$ (one of the

\footnotetext{
${ }^{37}$ See Joseph Goldstein, Anna Freud, 92 YALE L. J. 219, 219-20 (1982).

${ }^{38}$ The Catalogue of the Law School, LXI Official Register of Harvard University 74 (1964).

${ }^{39} \mathrm{Id}$.

${ }^{40}$ See The Catalogue of the Law School, LXII Official Register of Harvard University 73 (1965) (the course "speculate[s] about the possible relevance of this [psychoanalytic] theory to such legal issues as: conscious and unconscious intent and mistake in the law of wills, crimes, divorce and torts; guilt feelings and actual guilt in the law of evidence, crimes and employment; perception, rationality and memory in the law of evidence, torts and crimes; coercion and voluntariness in the law of the military, confessions, insurance, free press and race relations; and
} 
topics that was briefly discussed in the 1964-65 course $^{42}$ ). Alan Dershowitz taught both courses, this time not with the participation of Jay Katz, but of Alan Stone, Associate Professor in Psychiatry at the Harvard Medical School. This was the first contribution of Alan Stone to the HLS curriculum, a contribution that represented the beginning of a long and successful marriage between law, psychology, and psychiatry in the HLS curriculum. Stone, who graduated in psychology from Harvard College in 1950, and earned his M.D. from Yale Medical School in 1955, first earned a position as lecturer at Harvard Law School in 1969 and was (aptly) appointed Touroff-Glueck Professor of Law and Psychiatry in $1982 .{ }^{43}$ In 1983-84, Stone started teaching the course "Psychiatry and the Law" 44 - course that endured the passage of time, being still offered in 2012-13 as a reading group. ${ }^{45}$ Despite Katz's leaving, the influence of Yale was still very much present in this small curricular niche at HLS. First, both Dershowitz and Stone earned degrees from Yale. Second, the materials used both for "Psychoanalytic Theory and the Law" and for "The Legal Status of the Mentally Ill" were mimeographed from the book co-authored by Jay Katz, Joseph Goldstein, and Alan M. Dershowitz, Psychoanalysis, Psychiatry and the Law, published in $1967 .^{46}$

prediction and 'postdiction' in the law of juvenile delinquency, criminal attempts, and civil commitment.").

${ }^{41}$ See Id., at 71 ("This seminar will be devoted to an exploration of the variety of processes by which our society designates some of its members as 'mentally ill' and 'mentally healthy'; and to an evaluation of the consequences of such designations in light of their purposes. Drawing on such materials as hospital record, psychiatric and psychological reports, ... and writings of behavioral scientists, we will focus in detail on two major problems: (1) the substantive and procedural rules governing the involuntary confinement in, and release from, mental hospitals; and (2) the relevance of mental 'health' or 'illness' in determining who is 'competent' to establish legal relationships (e.g., contractual, familial, tortious, testamentary), to participate in the legal process (as e.g., judge, juror, witness, defendant, lawyer, subject for execution, psychiatrist), and to assume a variety of other responsibilities (e.g., policeman, teacher, citizen, soldier, employer, employee).").

${ }^{42}$ See The Catalogue of the Law School (1964), supra note 38, at 74 (the course "will also touch on: ... assumptions underlying the legal treatment of mental illness sometimes as a provoking event (civil commitment), other times as an 'excusing' condition (insanity defense)."). 43 Alan Stone's faculty page at Harvard Law School, http://www.law.harvard.edu/faculty/directory/index.html?id=73.

${ }^{44}$ There is a strong possibility that the course was offered for the first time in the curricular year of 1982-83, after Stone's appointment as Touroff-Glueck Professor of Law and Psychiatry. However, that year's catalogue was missing from the Registrar's Office, so I cannot be sure of that.

${ }^{45}$ See http://www.law.harvard.edu/academics/curriculum/catalog/index.html.

${ }^{46}$ See Jay Katz, Joseph Goldstein, \& Alan M. Dershowitz, Psychoanalysis, PSYCHIATRY AND THE LAW (1967). 
In 1966-67, the course "The Legal Status of the Mentally Ill" did not feature in the curriculum, but a course with some degree of overlap with it was added: In "The Prediction and Prevention of Anti-Social Conduct", Dershowitz and Stone "consider[ed] the variety of devices which authorize the state to intervene and prevent certain socially harmful results before their consummation. ... [The course examined] one particular predictive-preventive device commitment of dangerous mentally ill persons - in great detail." ${ }^{.47}$ From 196869 onwards, however, the three courses - "The Prediction and Prevention of Harmful Conduct", "Psychoanalytic Theory and Legal Assumptions", and "Mental Abnormality and the Law" (now taught by Stone alone, using the case method and materials extracted from Stone \& Stone, The Abnormal Personality Through Literature $\left.{ }^{48}\right)^{49}$ - co-existed in the curriculum.

Throughout this period, "Medico-Legal Problems" was a constant presence in the curriculum, while other "imperfect" law and mind sciences courses were introduced: "Human Relations Problems in Legal Practice" aimed, among other things, to "increase the future lawyer's ... sensitivity to the behavioral forces that may be operative" in the course of their work; "Youth and Crime", following a reappearance of "Juvenile Delinquency" for one year (taught by Livingston Hall), ${ }^{51}$ made "a detailed comparative analysis of current major theories of deviant conduct [by children] drawn primarily from psychological, social and cultural modes of explanation"; 52 and "Law and Sociology", which, despite sociology not being a mind science unlike social psychology, ${ }^{53}$ gave consideration to writings in this branch of psychology. ${ }^{54}$ 81 (1966).

${ }^{47}$ The Catalogue of the Law School, LXIII Official Register of Harvard University 80-

48 See Alan A. Stone \& Sue S. Stone (eds.), The Abnormal Personality THROUGH LITERATURE (1966).

${ }^{49}$ See The Catalogue of the Law School, LXV Official Register of Harvard University 92 (1968).

${ }^{50}$ The Catalogue of the Law School (1966), supra note 47, at 65. In 1971-72, the term "behavioral forces" was replaced by "emotional and psychological forces". See The Catalogue of the Law School, LXVIII Official Register of Harvard University 80 (1971).

${ }^{51} I d$., at 67.

${ }^{52}$ The Catalogue of the Law School, LXIV Official Register of Harvard University 92 (1967).

${ }^{53}$ There is often confusion regarding the distinction between social psychology and sociology. Although there is a great degree of overlap between both, the difference is one of perspective:

Where sociology attempts to explain the macro and micro environmental variables that influence peoples' behavior, social psychology hones in on the individual influences and behaviors that enable us to predict and better understand people's thoughts and behaviors. ... Perhaps the best way to describe social psychology through use of example is by contrasting it against sociology. Let's take the issue of marriage and divorce. If divorce rates start to 
Based on the considerable number of courses drawing on insights from the mind sciences that bloomed during the years 1964-69, it is safe to say that this period corresponded to the inception of the mind sciences as an established curricular phenomenon at HLS. This inception was much due to the influence of Dershowitz and Stone, an influence that would span decades. Also, outside HLS, awareness of the value of the mind sciences for deepening the understanding of law and legal theory was increasing: the American Psychology-Law Society was founded in the late 1960s.

Having detected this movement towards a greater exploration of the interactions between law and certain mind sciences, the question about the reasons underlying it is in order. Why did the law curriculum suddenly incorporate mind science disciplines? Since these disciplines develop outside the law school and are the result of research and scholarly communication that happens outside the legal academic environment, I hypothesized that the law school curriculum was reacting to such developments, by incorporating insights that were growing in popularity in their respective fields. As the figures below show, a search in Google Ngram Viewer - a service that allow users to trace the use of strings of words (and, consequently, of concepts and ideas) over the last years, decades, even centuries, through a visualization of the rise and fall of particular stings of words across 5 million books - supports this hypothesis. The peaks in the graphs represent a growth in usage of the terms "psychiatry", "psychoanalytic theory", and "mental health". This growth in usage seems to illustrate a growth in popularity of these concepts in their respective domains. Concepts and ideas are likely to be discussed and subject to scrutiny in the domains in which they were generated first. After being sanctioned by the gatekeepers of the domain, these concepts and ideas spread across other fields of studies that might benefit from the import thereof. I argue that this is what the law curriculum did. After the growth of the body of knowledge in psychiatry, psychoanalysis and mental illness and the recognition of its scientific validity, the law school proceeded to import this knowledge. Nonetheless, the graphs seem to suggest that these developments start occurring some twenty years before they are incorporated into the HLS curriculum. The sharp increase in the usage of the three terms searched for starts around the late 1940s and only in mid-to-late 1960s do they appear in the law curriculum. However, the accuracy

spike, a sociologist might start to look at how economic and societal pressures have pressed on the fabrics of the marriage and tested its strength. Social psychologists, however, would take it a step further and example how such pressures are interpreted by couples in marriage and how they respond to them.

Jesse Lawson, Difference between Sociology and Social Psychology, Lawsonry - The Online Journal for Social Progress, http://www.lawsonry.com/674-difference-between-sociology-andsocial-psychology/ (citations omitted).

${ }^{54}$ See The Catalogue of the Law School (1965), supra note 40, at 70. 
of graphs generated by Google Ngram Viewer such as these must not be exaggerated. Google Ngram Viewer's reliability has been questioned, mainly due to its inability to take the context in which the word is inserted into account $^{55}$ and to problems with the optical character recognition system on which it is based. ${ }^{56}$ Nevertheless, and although this data is not indubitable proof of the above-stated hypothesis, the consistency in the patterns of the three graphs offers some support for it.

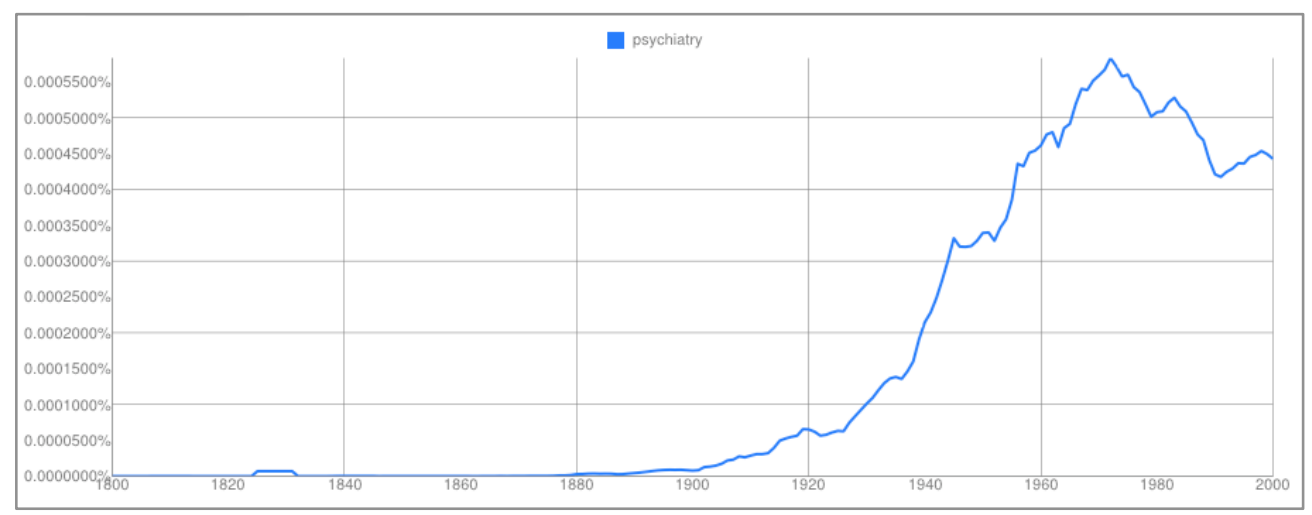

Figure 2 - Evolution of the use of the term "psychiatry" from 1800 to 2000.

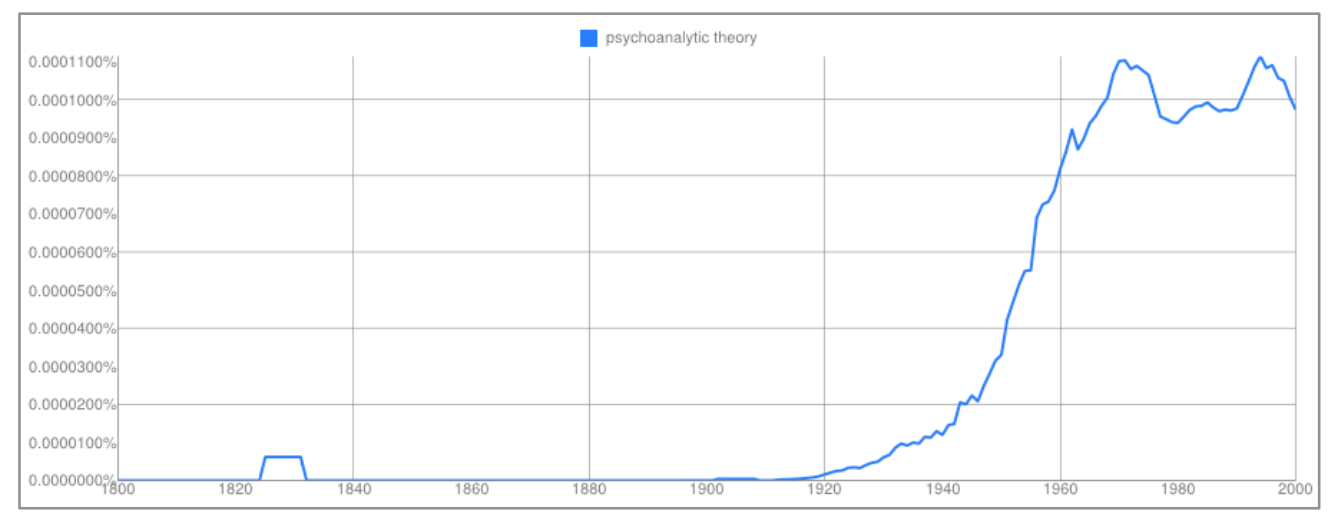

Figure 3 - Evolution of the use of the term "psychoanalytic theory" from 1800 to 2000.

${ }^{55}$ See http://aelang.net/wordpress/2011/10/ngrams-the-perfect-little-assistant-to-life/.

${ }^{56}$ See Danny Sullivan, When OCR Goes Bad: Google's Ngram Viewer \& The F-Word, http://searchengineland.com/when-ocr-goes-bad-googles-ngram-viewer-the-f-word-59181 . 


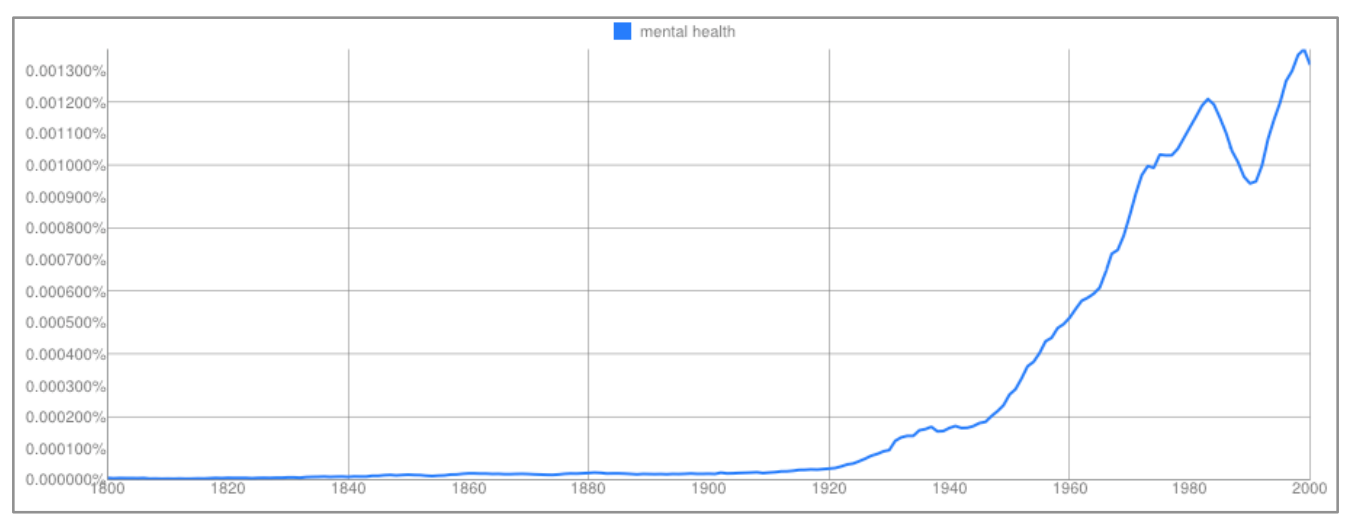

Figure 4 - Evolution of the use of the term "mental health" from 1800 to 2000.

\section{1969-89: The First Stabilization Period}

The period between 1969 and 1989 was one of little fluctuation in the number of both "perfect" and "imperfect" mind sciences courses in the HLS curriculum. Courses like "Prediction and Prevention of Harmful Conduct", "Psychoanalytic Theory and Legal Assumptions", "Mental Abnormality and the Law" take root in the curriculum. Some courses requiring some readings in psychology - like "The Lawyer as a Negotiator", 57 "Interdisciplinary Approaches to Dispute Settlement", 58 and "Jurisprudence - Knowing, Reasoning and Judging",59 - made brief appearances in the curriculum throughout this period. It is worth noting than in the $80 \mathrm{~s}$ the number of interdisciplinary courses started to increase exponentially; the number of mind sciences courses did not, however, increase in a proportional way.

${ }^{57}$ See The Catalogue of the Law School, LXXII Official Register of Harvard University 141 (1975) ("The materials used in this course consist of writings by lawyers, psychologists, and psychiatrists. ... Other materials, such as those chosen from social psychology, deal with the negotiation process only tangentially.")

${ }^{58}$ See The Catalogue of the Law School 80 (1980) ("This course will study the different ways that legal professionals, sociologists, political scientists, anthropologists, psychologists, and historians think about such problems in the dispute settlement as access to justice and court congestion ....")

${ }^{59}$ See The Catalogue of the Law School 135-36 (1988) ("The study and practice of law depends on claims and activities of knowing, reasoning, and judging. ... Twentieth century scholars in psychology, physics, philosophy, religion and other fields have articulated sharply contradicting ideas about how we know, what counts as reason, and how, why, and when we judge. This seminar will frame a conversation between legal thinkers and scholars from other disciplines about these themes."). 
Nonetheless, as previously mentioned, in 1983-84, after Alan Stone got the Touroff-Glueck chair, the course in "Psychiatry and the Law" was born. The course has been available, although not continuously, for almost 30 years, being still offered in 2012-13.

This stagnation did not reflect what was happening in the legal realm. Several fora for dissemination of research in law and mind sciences have been created since the 1970s, like the journals Law and Human Behavior, Behavioral Sciences and the Law, and Law and Psychology Review. Moreover, in courts, too, psychology became more and more used: "[e]xpert testimony on psychological and psychiatric issues became more accepted ... and the use of various psychological syndromes became increasingly common ... as defenses to criminal charges." ${ }^{60}$ Harvard's curricular response to this explosion in popularity of law and mind sciences in general, and law and psychology in particular, seemed to come in the years 1989 to 1997.

\section{1989-97: The First Golden Period}

The twenty years of relative stagnation of the influence of the mind sciences in the HLS curriculum were followed by a period of great diversification both in the courses exploring the implications of the study of the mind to the law and in the faculty teaching this kind of courses. In addition to the already-classic "Prediction and Prevention of Harmful Conduct", "Psychiatry and the Law", and "Psychoanalytic Theory and Legal Assumptions", three courses that I considered to be "perfect" mind sciences courses were added.

Roberto Unger joined Alan Stone in "explor[ing] certain modern ideas about the forms of individual happiness that satisfy an ambitious, but defensible

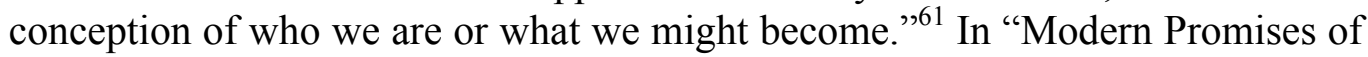
Happiness", while Unger "approache[d] these ideas from the twofold perspective of their connection with the progress of democracy and of their ambivalence toward the moral teachings of Christianity", 62 Alan Stone, "from the standpoint of psychoanalytic theory, consider[ed] the promises of happiness as they relate to the history of desire in the individual and the development of personal identity."63

Alan Dershowitz invited Stephen Jay Gould, Professor of Geology in the Faculty of Arts and Sciences, Alexander Agassiz, Professor of Zoology in the Museum of Comparative Zoology, and Robert Nozick, Arthur Kingsley Porter Professor of Philosophy in the Faculty of Arts and Sciences, to co-teach a course in "Thinking About Thinking". The goal of the course was to understand

\footnotetext{
${ }^{60}$ Blumenthal, supra note 4, at 16 (citations omitted).

${ }^{61}$ See, e.g., The Catalogue of the Law School (1989).

${ }^{62} \mathrm{Id}$.

${ }^{63} \mathrm{Id}$.
} 
"distinctive modes of thinking in three fields. Topics ... include[d]: prediction of the future; reconstruction of the past; probabilistic inferences; particular moral, social and religious issues." 64

Connecting his interests in law, psychiatry, and cinema ${ }^{65}$ together, in 1996-97, Stone started teaching a seminar in "Law, Psychology and Morality: An Exploration Using Film", examining "subjects at the intersection of law, psychology, and morality using film and film commentary as text.",66

Furthermore, from 1991 to 1996, Charles Nesson and David Cope - who would later integrate the new wave of law and mind sciences teachers at HLS offered a course in "The Persuasive Power of Moral Argument", that included readings from a number of disciplines, including psychology. ${ }^{67}$

The curricular year of 1989-90 is a year of pronounced prevalence of the mind sciences in relation to law and economics, at least in terms of curricular offerings. Under the heading of "Law \& Other Disciplines", while there were just two courses in economic analysis of law, taught by Steven Shavell, Lucian Bebchuk, and Louis Kaplow, there were five "perfect" law and mind courses. ${ }^{6}$ This prevalence did not reflect the balance of forces between law and economics and law and mind sciences in legal scholarship. In fact, the panorama in legal scholarship was (and still is) quite the opposite of that in the HLS curriculum in the early 1990s. If psychology and other related mind sciences never really enjoyed widespread popularity as a framework for analysis of the law, economics did, although certainly more in the United States than in Europe. ${ }^{69}$ Among all the interdisciplinary approaches to the law, law and economics occupied an almost dominant position in American legal scholarship. Judge Posner's words help summarize this dominance:

Economic analysis of law has grown rapidly, has become the largest, most pervasive interdisciplinary field of legal studies in the history of American law, has palpably influenced the practice of law and judicial decisions, has launched lucrative consulting spin-offs, has spawned courses and textbooks in economic analysis of law, has influenced legislation (economic analysis of

\footnotetext{
${ }^{64} I d$.

${ }^{65}$ Alan Stone serves as the film critic for the Boston Review.

66 The Catalogue of the Law School (1996).

${ }^{67}$ See, e.g., The Catalogue of the Law School 152 (1991)

${ }^{68}$ See The Catalogue of the Law School 49 (1989).

${ }^{69}$ See Nuno Garoupa \& Thomas S. Ulen, The Market for Legal Innovation: Law and Economics in Europe and the United States, 59 ALA. L. REV. 1555 (2008) (arguing that the fact that the American market in higher education, in general, and in legal education, in particular, is much more competitive than the European market is the crucial explanation for this difference in receptivity to law and economics and to other types of legal innovations.).
} 
law played an important role in the deregulation movement), has made it de rigueur for law schools of the first and second ranks to have one or more economists on their faculty, has seeded a number of its practitioners in university administration and the federal judiciary, and has now crossed the Atlantic and begun making rapid gains in Europe. ${ }^{70}$

Indeed, "[e]conomists are popular. Well, perhaps not at dinner parties, but there is no disputing that within universities, think tanks, and government agencies, their ideas dominate the scene. In legal academia ... no other approach has been as influential as law and economics over the last half-century." "71 This prevalence of economics in relation to psychology may be explained by a fundamental difference in discourse between these two disciplines. Psychology's discourse is probabilistic, in that it aims at describing the likelihood that a certain action or event will occur. Differently, the discourse of economists emanates surety, being characterized by a higher degree of certainty, hence more in tune with the legal discourse. ${ }^{72}$ Thus, economic research tends to permeate legal studies more easily than psychological research. Adam Benforado, David Yosifon, and Harvard Law Professor Jon Hanson offer an alternative and somewhat more subtle explanation for the prevalence of the law and economics approach. These authors argue that the model of human behavior that economists proposed, a dispositionist model that takes human rationality as a given, is more in line with our intuitions about ourselves. We are generally averse to the idea that our behavior is deeply influenced by the situation we find ourselves in and that it is often less dependent on our dispositions than we think - and that is the account offered by social psychologists. "Social psychologists tend to be situationists in a dispositionist world." ${ }^{, 74}$ Against this scholarship landscape, the prevalence of the mind sciences over economics in the HLS curriculum in the early 90 s is even more remarkable.

\footnotetext{
${ }^{70}$ Richard A. Posner, The Sociology of the Sociology of Law: A View from Economics, 2 EUR. J. L. \& ECON. 265, 275 (1995).

${ }^{71}$ Adam Benforado \& Jon Hanson, Backlash: The Reaction to Mind Sciences in Legal Academia, in IDEOLOGY, Psychology, AND LAW 501 (Jon Hanson ed., 2012).

72 Oliver R. Goodenough, Can Cognitive Neuroscience Make Psychology a Foundational Discipline for the Study of Law?, in LAW AND PSYCHOLOGY: CURRENT LEGAL ISSUES Volume 9 77, 78 (Belinda Brooks-Gordon \& Michael Freeman eds., 2006). (suggesting that "[t]here is a triumphalism in the tone of law and economics writers that contrasts with the more tentative tone of law and psychology.")

${ }^{73}$ See Benforado \& Hanson, supra note 71, at 501-2; Jon Hanson \& David Yosifon, The Situation: An Introduction to the Situational Character, Critical Realism, Power Economics, and Deep Capture, 152 U. PA. L. REV. 129, 142-154 (2003-2004).

${ }^{74}$ Benforado \& Hanson, supra note 71, at 503.
} 
But this economic ethos of legal scholarship may change in response to new ideas and forces. Indeed, as it shall be seen, there are reasons to be optimistic in what regards the influence of psychology on legal studies.

\section{1997-2000: Crisis}

1997-98 was the annus horribilis of the mind sciences in the Harvard Law curriculum, at least in relation to law and economics. Students were offered six courses in economic analysis of law - "Economic Analysis of Law", "Economics and Public Law", "Economics of Regulation and Antitrust", "Law and Economics", "Law and Economics: Research Seminar", and "Law and Economics: Empirical Issues" - and only two in the intersection between law and mind sciences - "Psychiatry and the Law" and "Law, Psychology and Morality". This meant that there was not only a shift in curricular influence in favor of law and economics, but also a sharp decline in the number of mind sciences courses in absolute terms. The reincarnation of "Thinking About Thinking" in $1999^{75}$ was not enough to tilt the scales in favor of the mind sciences again.

\section{2000-10: The Second Golden Period}

For someone who spent days reading course catalogues in search of courses related to the mind sciences, the years 2000 represent a truly fascinating period. While perusing these ten catalogues, the level of adrenaline in my bloodstream increased substantially: new and incredibly interesting law and mind sciences courses popped up on every page!

Behavioralism's influence on the law curriculum began to be felt in 2000-01, with the introduction of two courses. The introduction of "Behavioral Law and Economics" resulted from the recognition that the traditional economic models of rational behavior were flawed. ${ }^{76}$ Decision-making scholars, like Paul Slovic, Amos Tversky, and Daniel Kahneman, ${ }^{77}$ started incorporating insights from psychology into economic studies, by using psychological concepts and methods to help understand the economic decisions of individuals. This

${ }^{75}$ See The Catalogue of the Law School (1999).

${ }^{76}$ See The Catalogue of the Law School 98 (2000) ("Analyses of legal processes often assume that people adhere to certain assumptions regarding rational behavior. A considerable emerging literature tests these assumptions using empirical evidence on actual performance of litigants and the courts, as well as experimental evidence on decision-making by judges and jurors. ... The seminar will begin with a brief overview of the principal findings in the psychology and economics literature concerning the rationality of individual behavior in general.").

${ }^{77}$ These authors made invaluable contributions for the launch of the field of behavioral economics. Daniel Kahneman's latest book brings together his and Tversky's lifetime research on judgment and decision-making. See Daniel Kahneman, Thinking, FAST And Slow (2011). 
eventually led to the birth of behavioral economics and, consequently, of behavioral law and economics. In "Law and Behavioralism", Jon Hanson - a scholar whose role in propelling the impact of the mind sciences in the HLS curriculum and in legal scholarship is likely to become as influential as that of Alan Dershowitz and Alan Stone in the 60s, 70s and 80s ${ }^{78}$ - recognized that "[c]ognitive psychology and behavioral sciences are playing an increasingly important role in legal theory and the law" 79 and, accordingly, analyzed behavioralism's implications for law.

Jon Hanson, director of the Project on Law and Mind Sciences at HLS (PLMS) ${ }^{80}$ and editor of The Situationist ${ }^{81}$, taught several courses dedicated to an investigation of the role of mind sciences in law and policy. In 2005-06, Hanson taught a seminar and writing workshop about "Choice" - a social-psychological analysis of "the growing place and role of 'choice' in conventional understandings of laws, markets, and many of the most salient policy debates in our culture - including abortion, sexual 'preference', school options, social security, welfare, election law, and many more." ${ }^{~} 2$ In 2008-09, leading up to the publication of the homonymous book that brought "many of the world's experts on ... [ideology, psychology, law and policy] together to examine the sometimes unsettling interactions between psychology, ideology, and law, and to better understand what, beyond and beneath the logic, animates the law", 83 taught the seminar "Ideology, Psychology, and Law". Although it focuses on the importance of studying the causes and implications of ideology, the course description is a splendid account on why the study of mind sciences can be valuable to achieve a more realistic understanding of law and policy:

Most judges and legal scholars tend to disregard or downplay the role of ideology in the creation and implementation of laws and in the development of legal theory. Similarly, since World War II, social scientists have paid surprisingly little attention to ideology

${ }^{78}$ That may well be the reason why Jon Hanson will be the first Alan Stone Professor of Law, according to what Alan Stone himself told me in conversation.

${ }^{79}$ The Catalogue of the Law School 150 (2000).

${ }^{80}$ The Project is described as "a resource for scholars, students, and citizens with an interest in understanding the implications of social psychology and other related mind sciences for law and policy." http://isites.harvard.edu/icb/icb.do?keyword=k13943\&pageid=icb.page63708.

${ }^{81}$ The Situationist is an online forum "for scholars, students, lawyers, policymakers, and interested citizens to examine, discuss, and debate the effect of situational forces - that is, non-salient factors around and within us - on law, policy, politics, policy theory, and our social, political, and economic institutions." http://thesituationist.wordpress.com/about/.

${ }^{82}$ The Catalogue of the Law School 72 (2005).

${ }^{83}$ See Jon Hanson (ED.), IdeOlogy, Psychology, AND LAW (2012). 
as a topic of research. That is now rapidly changing as social psychologists and other mind scientists have begun to study, among other things, the characteristics and situations of people drawn to different dogmas. The latest research suggests that ideology is more a manifestation of implicit processes, motives, and human needs than a product of careful reasoning and explicit choices. The evidence indicates that when we embrace an ideology or claim to rise above it--whether as citizens, judges or scholars-our efforts are motivated and often undermined by our social and psychological situations. The seminar will be built largely around chapters of a book now in progress in which mind scientists and legal scholars examine the most recent research on the sources and consequences of ideology and discuss the possible implications of that research for policy, politics, law and legal theory. ${ }^{84}$

One idea around which much of Hanson's scholarship has revolved is that of situationism. ${ }^{85}$ Situationism refers to the idea according to which "[w]e are too ready to read personality and character traits into the behavioral drama and too resistant to see stage settings as the basis for the action." 86 This tendency to attribute behavior to the individual's internal traits, and the corresponding failure to recognize the influence of situational forces on that behavior is called "the fundamental attribution error". ${ }^{87}$ Against this readiness to put too much weight on individual differences, the work of scholars like Hanson has contributed to an understanding that human behavior relevant to the law heavily depends on these social constraints. Hanson brought this perspective into the Harvard Law classrooms in 2008-09 with the course "Situationism". ${ }^{88}$ In an effort to have the students actively participating in scholarly exploration of the intersection between law, social psychology, social cognition, cognitive neuroscience and

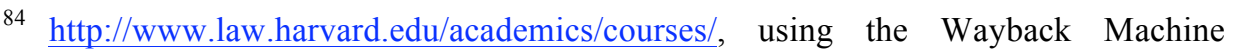
(http://archive.org/web/web.php).

${ }^{85}$ See, e.g., Jon D. Hanson \& David Yosifon, The Situational Character: A Critical Realist Perspective on the Human Animal, 93 Georgetown L. J. 1 (2004); Jon D. Hanson \& David Yosifon, The Situation: An Introduction to the Situational Character, Critical Realism, Power Economics, and Deep Capture, 152 U. PA. L. REV. 129 (2003); Jon D. Hanson \& Michael McCann, Situationist Torts, 41 LoY. L. A. L. REV. 1345 (2007-2008).

${ }^{86}$ Philip G. Zimbardo \& Michael Leippe, The Psychology of Attitude Change AND SOCIAL INFLUENCE 93 (1991)

${ }^{87}$ See, e.g., LeE Ross \& Richard E. Nisbett, The Person And the Situation 4 (1991) ("People's inflated belief in the importance of personality traits and dispositions, together with their failure to recognize the importance of situational factors in affecting behavior, has been termed the 'fundamental attribution error."').

88 http://www.law.harvard.edu/academics/courses/, using the Wayback Machine (http://archive.org/web/web.php). 
other mind sciences, Hanson would require them to write short papers, literature reviews, interviews, and article summaries - "some of which to be published on The Situationist Blog or other blogs or in non-law-review periodicals." 89 This writing workshop format has been adopted by Hanson in most of his mind science courses - the "Law and Mind Sciences: Blogging Workshop",90, offered in 2009-10, is an example of that.

Leaving Hanson's contribution aside, and going back to a more chronological approach, the curricular year of 2001-02 was a year of innovations in the Negotiation realm. Roger Fisher and Daniel Shapiro taught "Negotiation: Dealing with Emotions", with the goal of helping future negotiators learn how to deal with their emotions during the negotiation process. In addition, Robert Bordone, Director of the Harvard Negotiation and Mediation Clinical Program, taught "Negotiation and Dispute Resolution - Interdisciplinary Research", which involved an examination of different perspectives on negotiation, such as behavioral decision theory, cognitive psychology, and social psychology. ${ }^{91}$

In 2002-03, Dershowitz invites Stephen Kosslyn, John Lindsley Professor of Psychology in the Faculty of Arts and Sciences, to co-teach a course titled "The Neuroscience of Law: Can a Legal System be Grounded in Knowledge about the Brain?". The courses revolved precisely around that question: "can facts about the brain be used as foundations for a legal system?" 92

In 2003-04, two new courses emerged: "Laws of Deception", by Bruce Hay; and "Law and Psychology: The Emotions", by David Cope, that has remained in the curriculum ever since. "Law and Psychology: The Emotions"

offer[s] students a chance to explore what is missing form the traditional law school rational actor model of human behavior through discussion of readings primarily from psychology (but with contributions from biology, philosophy, an literature) about the nature and operation of emotions in persuasion and negotiation, gender differences in emotional experience and expression, and the role of emotions in moral and legal decision making. ${ }^{93}$

In "Laws of Deception", Bruce Hay conducted a discussion of the problems arising out of the separation between truthful and false statements that legal systems face. ${ }^{94}$

\footnotetext{
${ }^{89} I d$.

${ }^{90} \mathrm{Id}$.

91 See The Catalogue of the Law School (2001)

92 The Catalogue of the Law School (2002)

${ }^{93}$ The Catalogue of the Law School 190 (2003).

${ }^{94}$ See id., at 169.
} 
In 2005-06, Bruce Hay taught a course in "Law and Mind", which would examine "some of the intersections between the law and human mental processes such as language, perception, cognition, decision-making, and memory." The central themes of this course are central themes of the present paper's normative part too: "(1) how research on the mind can help us understand or resolve problems of law and policy, and (2) the legal system's ambivalent reception of such research." 95

In 2006-07, now Administrator of the White House Office of Information and Regulatory Affairs Cass Sunstein taught a course in "Law and Human Behavior" as a Visiting Professor. Co-author of the book Nudge: Improving Decisions About Health, Wealth, and Happiness, ${ }^{96}$ that invites the reader to enter a world in which humans' bounded rationality is a given, Sunstein brings this approach into the classroom. "Law and Human Behavior" covered topics like health law, social security reform, and antidiscrimination law, but always "with special reference to how real people really behave." 97 The course was taught through the lens of behavioral law and economics and a similar version was offered in 2008-09 (now with Sunstein as a permanent professor at Harvard, after having left Chicago for personal reasons ${ }^{98}$ ) under the name of "Behavioral Law and Economics."

In the years 2007-08 and 2008-09, cognitive science was especially en vogue in the HLS curriculum. In 2007-08, Visiting Professor Henry Smith - now Fessenden Professor of Law at Harvard - led a reading group examining the relevance of recent findings in cognitive science for legal studies. In 2008-09, Visiting Professor Dan Kahan taught "Law and Cognition", examining how cultural worldviews ${ }^{99}$ and other social and psychological affect the way legal decision-makers think. The seminar was offered again in 2011-12.

95 The Catalogue of the Law School 109 (2005).

96 See Richard H. Thaler \& CASs Sunstein, Nudge: Improving Decisions About HEALTH, WEALTH, AND HAPPINESS (2008).

97 http://www.law.harvard.edu/academics/courses/, using the Wayback Machine (http://archive.org/web/web.php).

${ }^{98}$ The personal reasons seemed to be related to the fact that he was seeing Samantha Power, professor of public policy at Harvard Kennedy School, who he ended up marrying in July 2008. For more gossip on this topic, see David Lat, The Real Reason Cass Sunstein's Going to Harvard? He's Got the Power, Above the Law, http://abovethelaw.com/2008/02/the-realreason-cass-sunsteins-going-to-harvard-hes-got-the-power/.

${ }^{99}$ A great part of Dan Kahan's scholarship is based on the theory of cultural cognition, according to which people shape their perceptions of facts according to their cultural values. See, e.g., Dan M. Kahan \& Donald Braman, Cultural Cognition and Public Policy, 24 YALE L. \& POL'Y REV. 149 (2006); Dan M. Kahan, Hank Jenkins-Smith, \& Donald Braman, Cultural Cognition of Scientific Consensus, 14 J. Risk RESEARCH 147 (2011); Dan M. Kahan, Culture, Cognition, and Consent: Who Perceives What, and Why, in “Acquaintance Rape” Cases, 158 U. PA. L. REV. 729 (2010); Dan M. Kahan, Donald Braman, Geoffrey Cohen, Paul Slovic, \& John 
Finally, in 2009-10, besides the ones already mentioned, two other "perfect" mind sciences courses were offered. Dan Simon, Professor of Law and Psychology at the University of Southern California Gould School of Law, taught "Law and Psychology: Wrongful Convictions", which "examine[d] the operation of the criminal justice system through the lens of experimental psychology. The psychological research will be used to analyze why and how the criminal process results in mistaken verdicts, as it is occasionally prone to do." 100 And in "Law and the Unconscious" Bruce Hay discussed the relevance that cognitive and psychoanalytic theories of the unconscious have to law. ${ }^{101}$

I characterized the years 2000 to 2010 as a golden period for mind sciences mainly due to the profusion of "perfect" law and mind sciences courses; indeed, the trends were identified based on these courses only. It is worth noting, however, that this period was also a fertile one in terms of "imperfect" courses. Throughout these ten years, various were the courses that, despite not focusing mainly on the interconnection between law, policy, and mind, drew on insights from mind sciences: "Power, Beauty, Sex, and Violence", with Diane Rosenfeld; "Regulation and Allocation of Risk", with David Rosenberg and David Cope; "Sexual Orientation and the Law", with William B. Rubenstein; "Taboo Subjects", with Alan Dershowitz; "Motivation", with William Fisher and Yochai Benkler, among others. Moreover, the courses taught by Alan Stone - "Law, Psychology and Morality: An Exploration Through Film" and "Psychiatry and the Law" - were consistently offered during these ten years.

One main idea comes out of this rather exhaustive (my apologies for that!) overview of the law and mind sciences courses that populated the HLS curriculum in this period: a new wave of law and mind science thinkers at Harvard composed by Jon Hanson, Cass Sunstein, Bruce Hay, and David Cope, ${ }^{102}$ combined with the ever-present influence of Alan Stone and, although in a lesser degree in this decade, of Alan Dershowitz, generated a period of intense exploration of the implications of different mind sciences for the law in the HLS classrooms.

Gastil, Who Fears the HPV Vaccine, Who Doesn't, and Why? An Experimental Investigation of the Mechanisms of Cultural Cognition, 34 L. \& HUMAN BEHAVIOR 501 (2010).

$100 \mathrm{http} / / / \mathrm{www}$. law.harvard.edu/academics/courses/, using the Wayback Machine (http://archive.org/web/web.php).

${ }^{101}$ See id.

${ }^{102}$ To be sure, some of the teaching and scholarly writings of other HLS faculty members are informed by the work of mind scientists. According to Jon Hanson, "Lani Guinier, Bob Bordone, Martha Minow, Duncan Kennedy, Charles Ogletree, Bob Mnookin, Larry Lessig, Diana Feldman, Bruce Hay, Yochai Benkler, Glenn Cohen, and David Cope come to mind, and I'm surely forgetting some. Among our visitors this year, Dan Kahan and Martha Chamallas are prominent leaders in this interdisciplinary approach.” Jon Hanson on Law and Mind Sciences, The Situationist, http://thesituationist.wordpress.com/2012/03/15/jon-hanson-on-law-and-mindsciences/. 


\section{2010-13: The Second Stabilization Period}

It is still early to understand if there is a new trend forming in terms of law and mind sciences in the HLS curriculum. One thing is certain, though: in 2010-11 the number of "perfect" courses dropped to four - "Law and Mind Sciences", "Law and Psychology: The Emotions", "Law, Psychology, and Morality: An Exploration Through Film", and "Psychiatry and the Law". But the number seemed to remain more or less stable in 2011-12 and 2012-13, which leads me to ask if we are entering a second stabilization period. So far, the tendency seems to be for the mind sciences to be present in the HLS curriculum through the offering of three of four "perfect" courses per year, much like what happened during the 1969-1989 period.

\section{The CASE for the Proliferation of LAW AND Mind Sciences Courses in THE LAW SCHOOL CURRICULUM}

\section{Are Mind Sciences a Fundamental Part of the "Good Law Curriculum"?}

Before providing an answer (however tentative) to this question, reflection must be put into a previous one: is there such a thing as the good law curriculum? Eleanor M. Fox reframes this question. In The Good Law School, The Good Curriculum, and the Mind and the Heart, ${ }^{103}$ she adopts the vantage point of the good law student: "What would the good law student, imbued with long-range interests and perfect information, demand?"104 She acknowledges that different law schools have different personalities, and that it is ill-advised to recommend a standard law curriculum that does not give due regard to these differences. ${ }^{105}$ However, "an eclectic law school", like HLS

will provide several models: e.g., the student whose aspirations is to help people; the student who wants to be a big-firm (or a littlefirm) lawyer; the student who wants to make his mark in government service; the student who wants to be a law teacher; the student whose challenge is to learn the intellectual richness of the law. ${ }^{106}$

Admittedly, it is to a school like Harvard that the proposal made in the present section is addressed. By "a school like Harvard" I am not referring to a top-5 law

${ }^{103}$ See Eleanor M. Fox, The Good Law School, The Good Curriculum, and the Mind and the Heart, 39 J. LEGAL EDUC. 473 (1989).

${ }^{104} \mathrm{Id}$., at 484 .

${ }^{105}$ See id., at 475.

${ }^{106} \mathrm{Id}$. 
school, but to a school that is comprehensively heterogeneous, a school that is diverse enough in its goals to train students to follow any of the above-stated career paths. In a law school like that - which, if you exclude the goal of teaching students to be law teachers, which seems to be reserved to a very small number of institutions, seems to be representative of the majority of U.S. law schools should the mind sciences integrate the curriculum?

First, it must be acknowledged that law and some of the disciplines of the mind have a lot in common. This similarity is particularly evident if one compares law with psychology. Law and psychology are both "exciting science[s] of people, not ... boring science[s] of molecules", ${ }^{107}$ in that they are both concerned with the actions and thoughts of the individual. Law aims to control and regulate human behavior, which involves an implicit prior step: to predict and explain such behavior. That prior step of predicting and explaining human behavior (and, to a certain extent, controlling it) is the focus of psychology. An argument can thus be made that "[e]very branch of law, every legal regulation within each branch, every single person making or administering the law needs psychology[, that] [n]o law is "free of psychology'."108 The overlap between both disciplines is so intense that some authors go so far as saying that "law should be characterized as a component of psychology" 109 and that "law can be seen as an implicit ... science of mind ... [while] psychology is the explicit science. $" 110$ Bold opinions aside, because law is largely based on assumptions about human behavior, the conclusion that it should take the insights of psychology - the science that studies that behavior - into account seems inescapable, unless lawyers argue that human behavior is random and that as a consequence any studies of it are unhelpful, which sounds like a rather implausible argument to make. ${ }^{11}$

Adam Benforado, a former student of Hanson's who later co-authored several articles with him, neatly summarizes why the "good law student" should want to have contact with the mind sciences, and why, consequently, these disciplines should have a solid presence in the law curriculum:

${ }^{107}$ Teresa M. Amabile, Within You, Without You: The Social Psychology of Creativity, and Beyond, in THEORIES OF CREATIVITY 61 (Mark A. Runco \& Robert S. Albert eds., 1990).

${ }^{108}$ Viktoras Justickis, Does the Law Use Even a Small Proportion of What Legal Psychology has to Offer?, in PSYCHOLOGY AND LAw: BRIDGING THE GAP 223 (David Canter \& Rita Žukauskienè eds., 2008).

${ }^{109}$ Shari Seidman Diamond, Foreword, in HANDBOOK OF PSYCHOLOGY OF LAW v-vi (Dorothy K. Kagehiro \& William S. Laufer eds., 1992) (arguing that because psychology studies human behavior, it necessarily needs to take law into consideration as one of the most powerful means of controlling that same behavior).

${ }^{110}$ Goodenough, supra note 72, at 77.

${ }^{111}$ See Andreas KaPARDis, Psychology AND LAw: A CRITICAL InTRODUCTION 7 (2003). 
[T] he mind sciences are important to incorporate into the law school curriculum for several reasons. Most notably, I think recent insights from psychology and neuroscience offer a much more accurate picture of how humans behave than the models provided by law and economics and other legal theoretical approaches. This is vitally important because current law students are the ones who will have an opportunity to change laws in the future. They need to understand how jurors make decisions, how eyewitness's memories work, and why people commit crimes, among many other things, in order to decide whether the laws on the books are likely to accomplish their goals or whether they might instead breed unfairness. In addition, and more generally, I think teaching mind sciences encourages students to be more critical consumers of conventional wisdom which is incredibly useful as a lawyer. ${ }^{112}$

"At the very least," Jon Hanson adds, "they will learn something about themselves." 113

\section{Who Should Decide?}

Given the benefits that law students would draw from being acquainted with the mind sciences, I now ask a different question: Who should decide whether the mind sciences should be included in the law curriculum or not? Two answers spring to mind: students and faculty should make the call. However, both these stakeholders in the future of the law curriculum are prone to making imperfect decisions. As Eleanor Fox observes,

[t]here is no perfect person or role through whose eyes we should try to examine how well the law school world fulfills its role as educational provider. ... [S]tudents lack information to appreciate what will prepare and enhance them as lawyers, and they have only a short-term interest in law school .... Faculty have information and have a long-run perspective but may be influenced by personal preferences as to what, when, and how they wish to teach. ${ }^{114}$

${ }^{112}$ E-mail from Adam Benforado (on file with author).

113 Jon Hanson on Law and Mind Sciences, The Situationist, http://thesituationist.wordpress.com/2012/03/15/jon-hanson-on-law-and-mind-sciences/.

${ }^{114}$ Fox, supra note 103 , at 474. 
Not only shouldn't the decision regarding the incorporation of the mind sciences in the law curriculum be taken by students or faculty, but it also won't. I argue that the expansion or contraction of the presence of mind sciences in the law curriculum is not likely to be the product of a deliberate process. This presence will continue to be a function of the developments that take place outside the law school, as discussed in Part II.2. These developments, if accepted by the gatekeepers of their respective domain as valuable contributions, will eventually reach legal scholars, by means of inter-domain scholarly communication. As seen, this process is likely to take several years. Nonetheless, legal scholars will eventually implement developments occurring in the mind disciplines in legal scholarship. If this scholarship is, in turn, judged by the gatekeepers of the legal domain - the editors and referees of major legal periodicals, the review committees of major funding agencies, and faculty of prestigious universities as being of value, it will be accepted for publication and this, in turn, will have repercussions in the faculty recruitment. Faculty that produce this kind of scholarship, if hired, are likely to teach courses exploring the intersection of law and mind sciences. Evidence supporting this assumption can be found in the historical review conducted in Part II.

As it has been discussed, the presence of mind sciences in the HLS curriculum is intimately dependent on the career and research interests of a very specific group of professors. If the "usual suspects" - Alan Stone and Alan Dershowitz, joined later by Jon Hanson, Bruce Hay, David Cope, and Cass Sunstein - weren't a part of Harvard Law's faculty, the influence of the mind sciences would have been felt almost only at an "imperfect" level. Hence, a proliferation of the number of mind science courses in the law curriculum will occur under two conditions: i) if more professors with research interests related to the interconnection between law and mind sciences are hired; ii) and this will only happen if the study of law through the lens of the mind sciences proves to be a respected interdisciplinary approach to the law and, possibly, a reasonable alternative to law and economics as the prevailing framework for interdisciplinary analysis of law. So the question about the future of the influence of the mind sciences in the law school curriculum and the question about the impact of law and mind as an interdisciplinary approach to the law are, in reality, one question only.

I further claim that law and mind is already succeeding in proving its value to the legal community. The growing influence of law and mind in legal academia is happening in a direct and indirect way.

In a direct way, psycho-legal research is both gaining more adepts and expanding to new areas. There is an increasing awareness that judges and other 
decision-makers are subject to cognitive biases; ${ }^{115}$ that neuropsychology has a word to say in certain legal topics; ${ }^{116}$ "and, more generally, [of] the power of emotions and other internal situational influences in how we formulate, interpret, and respond to laws." 117118 The number of scholars trained in both disciplines is increasing, as is the range of legal areas that are studied through a psychological lens. Moreover, the development of new approaches in psychology, like cognitive neuroscience, ${ }^{119}$ and in the intersection of law and psychology, like therapeutic jurisprudence, ${ }^{120}$ provides new opportunities for psychological research to permeate the legal realm.

In an indirect manner, psychology is already taking advantage of the dominance of economics in legal scholarship. First, law and economics had the effect of showing the value of interdisciplinary approaches to law to legal theorists and lawmakers. By "open[ing] their eyes and turn[ing] them from darkness to light", ${ }^{121}$ law and economics broke the ground that would later be explored by other interdisciplinary approaches, among which law and

${ }^{115}$ See, e.g., Guthrie, Rachlinski \& Wistrich, supra note 6; Guthrie, Rachlinski \& Wistrich, supra note 7; Stasser, Kerr \& Bray, supra note 8.

${ }^{116}$ See, e.g., Teneille Brown \& Emily Murphy, Through a Scanner Darkly: Functional Neuroimaging as Evidence of a Criminal Defendant's Past Mental States, 62 STAN. L. REV. 1119 (2010); Jessica R. Gurley \& David K. Marcus, The effects of neuroimaging and brain injury on insanity defenses, 26 BEHAV. SCI. \& L. 85 (2008); Joshua J. Knabb, Robert K. Welsh, Joseph G. Ziebell \& Kevin S. Reimer, Neuroscience, moral reasoning, and the law, 27 BEHAV. SCI. \& L. 219 (2009).

${ }^{117}$ Hanson \& McCann, supra note 85, at 1422.

${ }^{118}$ See, e.g., David A. Bright \& Jane Goodman-Delahunty, Gruesome Evidence and Emotion: Anger, Blame, and Jury Decision-Making, 30 LAw \& HUM. BEHAV. 183 (2006); Dan M. Kahan \& Martha C. Nussbaum, Two Conceptions of Emotion in Criminal Law, 96 CoLUM. L. REV. 269 (1996); Dan M. Kahan, Two Conceptions of Emotion in Risk Regulation, 156 U. PA. L. REV. 741 (2008).

${ }^{119}$ See Goodenough, supra note 72 , at 90 (arguing that cognitive neuroscience "can convert what have previously been intractable normative questions into matters of factual investigation", by explaining, for instance, why the theft of intellectual property is much more common than that of physical property: the human brain is more able to make an emotional link to the theft of physical objects, because they are physically perceptible, than to the theft of intangibles like intellectual property. Because this link is weaker in intellectual property goods, the individual will feel less deterred to take them illegally.). For a more skeptical view on the implications that neuroscience can have to legal doctrine and lawmaking, see Stephen J. Morse, New Neuroscience, Old Problems, in Neuroscience And the Law: Brain, Mind, And THE SCALES OF JUSTICE 157 (B. Garland ed., 2004). For a view that new neuroscience has the potential of operating change in law, see Joshua Greene \& Jonathan Cohen, For the law, neuroscience changes nothing and everything, 359 PHIL. TRANS. R. SOC. LOND. B 1775 (2004).

${ }^{120}$ See Bruce J. Winick, Therapeutic Jurisprudence: Enhancing the Relationship Between Law and Psychology, in LAW AND Psychology: CURRENT LEGAL Issues Volume 9 30 (Belinda Brooks-Gordon \& Michael Freeman eds., 2006).

${ }^{121}$ Acts 26:18, THE BIBLE (New International Version). 
psychology. ${ }^{122}$ In addition, as mentioned previously, decision-making scholars started to doubt some of the assumptions of the rational actor model and began to test these assumptions using psychological concepts and methods. This eventually led to the birth of behavioral economics and, consequently, of behavioral law and economics. In this sense, "the broader law and mind sciences movement can be viewed as a reaction to the dominance of law and economics in the legal academy over the last several decades.",123

\section{How Should We Go About It?}

Having concluded that exposure to social psychology, cognition, neuroscience and other mind sciences is beneficial for students and should thus be achieved through an inclusion of these insights in the law curriculum, a question still remains to be answered. How should we go about the inclusion of these insights into the law school classroom? How should professors who devote their research time to investigating the interactions between law and mind sciences communicate the conclusions that arise out of their research to their students? There are two ways of doing this: i) by teaching basic legal courses incorporating insights from the mind sciences - something that at least Dan Kahan, when at HLS, and Jon Hanson have been doing respectively in "Criminal Law" and "Torts"; or ii) by teaching what I coined "perfect law and mind sciences courses". question:

Again, I will resort to the clear-sightedness of Benforado to answer this

In the long term, I think that we must strive to deliver both types of courses in the law curriculum. Both offer great benefits. In the short term, I think that dedicated law and mind sciences courses are probably most viable. I find that teaching classic legal courses through the lens of the mind sciences takes a lot more work on the part of the professor. I bring in a considerable amount of psychology and neuroscience into my Business Organizations course, but it has taken a lot of time to think about how to do this and to actually execute it. There isn't a casebook out there that serves it up in a prepackaged format and, as a result, I don't see many professors who are not already experts in the field making the effort to adapt their courses. I also think that in a classic legal course (as opposed to a specialized seminar),

\footnotetext{
${ }^{122}$ See Hanson \& McCann, supra note 85, at 1420.

${ }^{123}$ Benforado, supra note 112.
} 
students have stronger expectations about how the course should be taught and may be more resistant to the novel perspective. ${ }^{124}$

Regarding the teaching of standard legal courses through the mirror of the mind sciences, a point must be added, despite its apparent obviousness. It is unwise to require professors teaching standard legal courses to incorporate the work of mind scientists if they do not have the knowledge necessary to effectively adopt such an approach of if they simply do not feel comfortable doing it. This paper should not be read as advocating the tyranny of the mind sciences. Although it highlights the benefits that such an approach would have for law students, it should not be understood as proposing its across-the-board implementation in the law curriculum. First, because such approach might just not be appropriate for certain areas of the law. Second, because the teaching style is something intimately connected not only to a law professor's research interests (some professors might simply not be interested in what mind scientists have to say), but also to his or her personality. If Jon Hanson and Dan Kahan give wings to their students' minds by employing this approach, it is certainly due to the fact that they are passionate about this way of teaching the law and deeply believe in its benefits; a professor forced to employ this approach - or, for that matter, any other approach that is not his or her own - would clip the wings of their students' minds, rather than making them fully flighted.

\section{CONCLUSION}

"As of today, the mind sciences are, well, hot."

Indeed, the mind sciences seem to be invading the pages of legal scholarship. More and more legal academics seem to be making efforts to become familiarized with the work of mind scientists and to integrate this work in their writings. ${ }^{126}$ The question is whether the law school curriculum will follow this trend and react to the increase in popularity of law and mind as an interdisciplinary approach with a corresponding increase in course offerings exploring this intersection. I have argued that law students would benefit from having contact with insights from the mind disciplines, both through basic legal

${ }^{124}$ Benforado, supra note 112.

${ }^{125}$ Hanson, supra note 113.

${ }^{126}$ See, e.g., Blumenthal, supra note 4, at 1 ("The use of ... psychology in particular ... to inform legal theory and practice is fast becoming the latest craze in the pages of legal academia"); Hanson \& McCann, supra note 85, at 1423-24 (there is an "increased awareness by legal academics of some of the more prominent social psychologists."); Student Association for Law and Mind Sciences, http://hlsorgs.com/salms/about/ ("Over the past decade, the number of law review articles citing to prominent mind sciences journals has skyrocketed...”). 
courses taught through the lens of those disciplines and through "law and"-type courses. The conclusion reached by the paper is that, given the rising popularity of this approach in legal scholarship, an increase in the law and mind curricular offerings is likely to occur as a result of a natural process. Because faculty recruitment depends on scholarly publication, if the law and mind approach is appraised by the academic community, scholars using this approach in their writings are likely to get their work published, thus boosting their chances of getting hired. Once hired, these scholars are likely to teach courses specifically exploring this interconnection ("law and" courses) or to teach basic courses imbued with insights from the mind sciences. In Harvard, however, after a fertile decade in the law and mind sciences ground, we seem to be entering a period of stabilization with three or four "perfect" courses offered per year. Hopefully, this paper will serve the function of strengthening the law and mind sciences movement at Harvard, by contributing to a better understanding of the importance of an expanded presence of the mind sciences in the curriculum. Students, lawyers, and the market of legal services in general would all benefit from this expanded presence. 